\title{
Neutral Ceramidase
}

National Cancer Institute

\section{Source}

National Cancer Institute. Neutral Ceramidase. NCI Thesaurus. Code C103904.

Neutral ceramidase (780 aa, $\sim 86 \mathrm{kDa}$ ) is encoded by the human ASAH2 gene. This protein is involved in ceramide hydrolysis. 